\title{
Karyotypes of three species of marine catfishes from Brazil
}

\author{
Vicente GOMES; PHAN Van Ngan \& Maria José de Arruda Campos Rocha PASSOS
}

Instituto Oceanográfico da Universidade de São Paulo

(Caixa Postal 66149, 05389-970, São Paulo, SP, Brasil)

- Abstract: The chromosomes of three species of fishes belonging to the family Ariidae - Netuma barba, Genidens genidens and Arius parkeri-were studied after conventional Giemsa staining. All three species have a diploid chromosome number of $2 \mathrm{n}=56$. The karyotype comprises 18 metacentric $(\mathrm{m}), 18$ submetacentric (sm), 18 subtelocentric (st) and 2 telocentric (t) pairs for $N$. barba; $12 \mathrm{~m}, 20 \mathrm{sm}, 20$ st and $4 \mathrm{t}$ pairs for $G$. genidens; $16 \mathrm{~m}, 16 \mathrm{sm}, 22 \mathrm{st}$ and $2 \mathrm{t}$ pairs for $A$. parkeri. The results obtained from these three species are compared with each other and with those found in literature.

- Resumo: Os cromossomos de 3 espécies de peixes da família Ariidae - Netuma barba, Genidens genidens e Arius parkeri - foram estudados após coloraçāo convencional com Giemsa. As três espécies apresentaram número modal diplóide de $2 n=56$. O cariótipo de $N$. barba compreende 18 pares de cromossomos metacêntricos $(\mathrm{m}), 18$ submetacêntricos $(\mathrm{sm}), 18$ subtelocêntricos $(\mathrm{st})$ e 2 telocêntricos ( $t$ ); o de G. genidens compreende 12 pares m, 20 sm, 20 st e 4 t; o de A. parkeri compreende $16 \mathrm{~m}, 16 \mathrm{sm}, 22 \mathrm{st}$ e $2 \mathrm{t}$. Os resultados obtidos são comparados entre si e com os de outros ariídeos encontrados na literatura.

- Descriptors: Chromosome, karyotype, Siluriformes, Ariidae.

- Descritores: Cromossomos, cariótipo, Siluriformes, Ariidae.

\section{Introduction}

There are about 2000 species of catfishes belonging to $\mathbf{3 1}$ families of which $\mathbf{1 3}$ are endemic to South America (Lauder \& Liem, 1983). Two of the catfish families became secondarily marine: the Plotosidac (ecltail catfishes) and the Ariidac (marine catfishes) (Kramer, 1990).

Members of Ariidae have circumtropical distribution and can be found along all the Brazilian coast. They are of great economical importance in certain regions, mainly for the Brazilian southern sea-side populations (Figueiredo \& Menezes, 1978). Numerous studies about this group covering various ficlds of scientific research have bcen developed; nevertheless, the systematics and

Contr. no. 759 do Inst. oceanogr. da Usp. the relationship between its members are still highly controversial (Higuchi et al.,1982; Suzuki \& Phan, 1990a).

Cytogenetical investigation has been used as one important tool that can help to elucidate problems related to systematics, evolution (Denton, 1973; Kirpichnikov, 1981) and population structure (e.g. Cestari \& Galetti Jr., 1992) of fishes. Karyotypes of only 129 species of freshwater and marine Siluriformes belonging to 13 families are available (Fitzsimons $e t$ al., 1988). Just five species of the family Ariidae have been karyotyped until now.

This work belongs to a series of studies that aims to verify genetical aspects of the ariid fishes of the estuarine region of Cananéia, using biochemical (Suzuki \& Phan, 1990 a,b), immunological (Gomes et al., in preparation) and cytogenetical (Gomes et al., 1990, 1992) methods. In this paper the karyotypes of Netuma barba (Lacépéde, 1803), Genidens genidens (Valenciennes, 1893) and Arius 
parkeri (Trail, 1832) (Siluriformes, Ariidac) are described and compared to the karyotypes of other ariids found in the literature.

\section{Materials and methods}

Specimens of N. barba, G. genidens and A.parkeri were collected in the estuarine region of Cananéia, São Paulo, Brazil (2501'S; $47^{\circ} 56^{\prime} \mathrm{W}$ ) from May 1981 to November 1986. Identification and denomination of the species were made after Taylor \& Menezes (1977) and Figueiredo \& Menezes (1978). The specimens were kept alive in tanks with running sea water and were injected intraperitoneally with $0.2 \mathrm{ml} / 100 \mathrm{~g}$ body weight of $0.5 \%$ colchicine in saline solution. Four to six hours after the injection the animals were sacrificed and the kidney was removed for chromosome preparation following the method described by LeGrande \& Fitzsimons (1976) with few modifications (Gomes et al., 1990).

The metaphases were photographed, the chromosomes were counted and the karyograms mounted from photographic prints. The size of the chromosomes in micrometers was estimated by measuring on the microscope one easily identifiable chromosome of a set with a micrometric eyepiece and then correlating these measures with those of all chromosomes of the same set taken from a photographic print (Denton, 1973). The arm ratios (long arm/ short arm) were calculated and terminology for centromeric position followed the criteria of Levan et al. (1964). To facilitate comparisons between species the chromosomes were also grouped in msm and stt types following Uyeno et al. (1983). To calculate arm numbers (AN), m (metacentric) and sm (submetacentric) chromosomes were considered as biarmed and st (subtelocentric) and $t$ (telocentric) as uniarmed.

\section{Results}

Metaphase plates were obtained from 20 specimens of $N$. barba, 11 males and 9 females, ranging from $181 \mathrm{~mm}$ to $293 \mathrm{~mm}$ in total length; 12 specimens of $G$. genidens, 4 males and 8 females, ranging from $145 \mathrm{~mm}$ to $240 \mathrm{~mm}$ in total length and 13 specimens of $A$. parkeri, 6 males and 7 females, ranging from $206 \mathrm{~mm}$ to $356 \mathrm{~mm}$ in total length.

In relation to $N$. barba, 203 mitotic spreads were examined, 132 for the males and 71 for the females. The cells with diploid number of $2 \mathrm{n}=56$ chromosomes account for $77.27 \%$ of male and $74.65 \%$ of female metaphases. The total length of the chromosomes in micrometers $(\mu \mathrm{m})$ taken as an average of 10 selected spreads ranged from
$6.29 \mu \mathrm{m}$ to $1.81 \mu \mathrm{m}$. The karyotype consisted of $9 \mathrm{~m}$ pairs, $9 \mathrm{sm}$ pairs, 9 st pairs and $1 \mathrm{t}$ pair (Fig. 1, A and B); AN is, therefore, 92 . The $19^{\text {th }} \mathrm{sm}$ pair is heteromorphic for the males and is constituted by the largest chromosome of the complement, averaging $4.13 \mu \mathrm{m}$, and by a smaller one with average total length of $2.49 \mu \mathrm{m}$ (Fig. 1, A).

Regarding to $G$. genidens, 112 mitotic plates were examined, 69 for the males and $\mathbf{4 3}$ for the females. The modal diploid number is $2 n=56$, representing $79.07 \%$ of the total countings for the males and $79.71 \%$ for the females. The total length of the chromosomes in micrometers $(\mu \mathrm{m})$ taken as an average of 10 selected metaphases ranged from $5.18 \mu \mathrm{m}$ to $1.77 \mu \mathrm{m}$. The karyotype consisted of $6 \mathrm{~m}$ pairs, $10 \mathrm{sm}$ pairs, $10 \mathrm{st}$ pairs and $2 \mathrm{t}$ pairs (Fig. 2, $\mathrm{A}$ and $\mathrm{B}$ ). The $\mathrm{AN}$ is 88 . No heteromorphism was observed between males and females.

From the preparations on $A$. parkeri it was obtained 193 mitotic spreads, 77 for the males and 116 for the females. The modal diploid number is $2 n=56$, representing $90.90 \%$ of the total countings for the males and $87.07 \%$ for the females. The total length of the chromosomes in micrometers $(\mu \mathrm{m})$ taken as an average of 10 spreads ranged from $4.25 \mu \mathrm{m}$ to $1.54 \mu \mathrm{m}$. The karyotype consisted of $8 \mathrm{~m}$ pairs, $8 \mathrm{sm}$ pairs, 11 st pairs and $1 \mathrm{t}$ pair (Fig. 3, A and B). The AN is 88 . No heteromorphism between males and females was observed in the chromosome plates examined.

Table 1 summarizes the results obtained in this and in other works ariid fishes.

\section{Discussion}

Comparisons of chromosome types between different species or even between the same species studied by different authors may present some problems due to possible mistakes in classifying the elements which are at the boundaries of two distinct morphological categories (LeGrande et al., 1984). For instance, the AN estimated for Ictalurus catus by LeGrande et al. (op. cit.) was 84 while by Hudson (1976) it was 64 to 68 . Due to this kind of difficulties the differences in AN could be less evident between some species and more obvious between others. This may, in part, be responsible for the great differences in arm number between the karyotypes of Bagre marinus and Bagre bagre reported by Fitzsimons et al. (1988) and by Gomes et al. (1990), respectively. On the other hand, it's also probable that most of the size variabilities of chromosome arms that alters AN among populations or species is natural and results from mechanisms such as deletions or duplications during karyologycal evolution. Bearing this in mind, useful comparisons can frequently be made. 

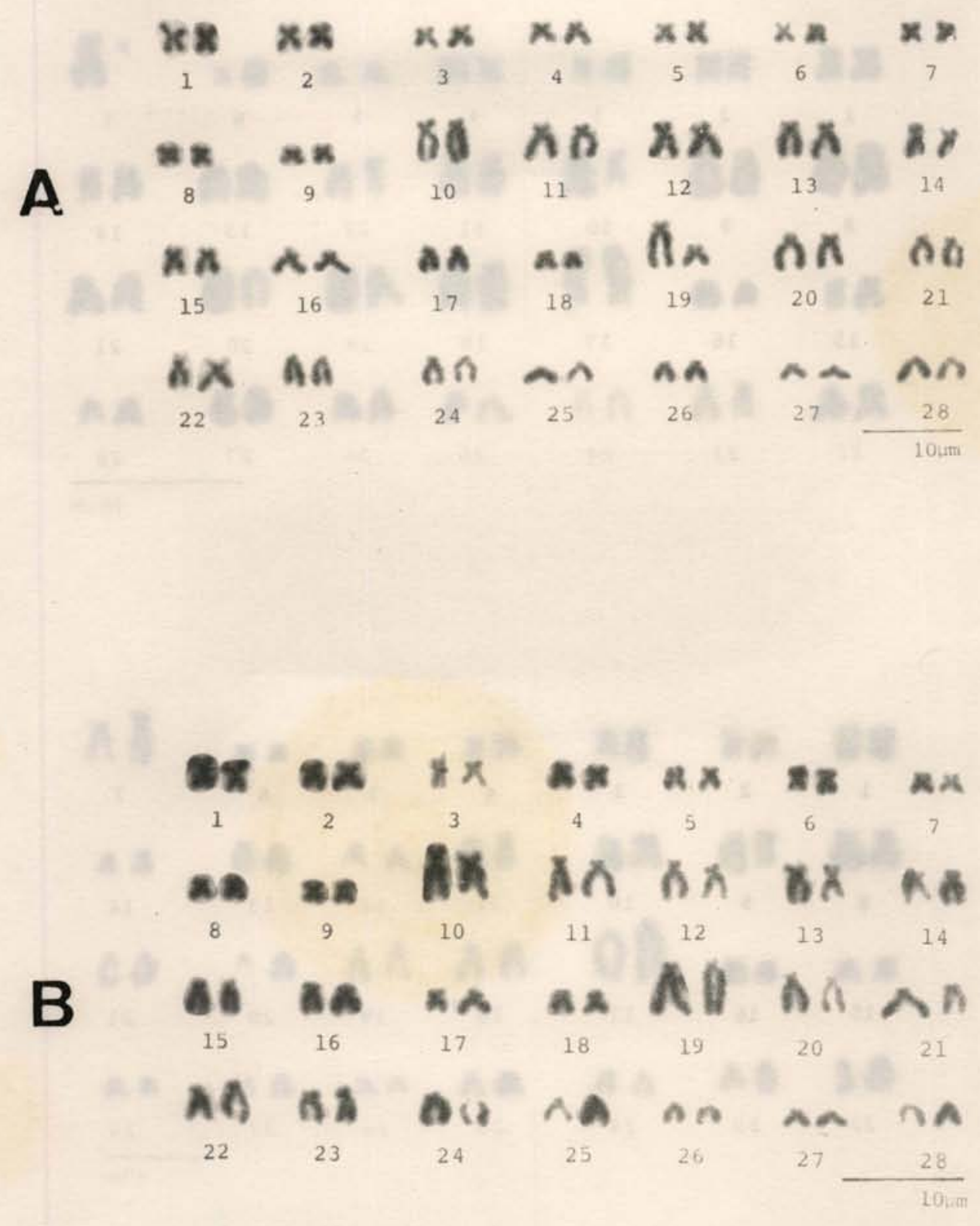

Fig. 1. Selected karyotype of a male (A) and a female (B) Netuma barba.

Examining the Table 1 it can be seen that all the fishes, including the three species presented here, have $2 \mathrm{n}=54$ or 56 chromosomes, and $\mathrm{AN}=80$ or more, except $B$. marinus $(\mathrm{AN}=74)$. The number $2 \mathrm{n}=56 \pm 2$ with high AN (around 80 ) has been considered by LeGrande (1981) as characteristics of the ancestral stock from where Siluriformes have evolved.

$N$. barba, G. genidens and A. parkeri have few t chromosomes (one to two pairs) that have not been reported for any other ariid fish. In some cases, however, this lack of $t$ chromosomes may be attributed to the fact that in describing karyotypes of fishes some authors prefer to group together the st and $t$ types to avoid mistakes and to facilitate comparisons. For instance, observing the illustration of the karyotype of $B$. marinus (Fitzsimons et al., 1988) one can notice that short arms are not distinguishable in some stt chromosomes that could possibly belong to $t$ types. 


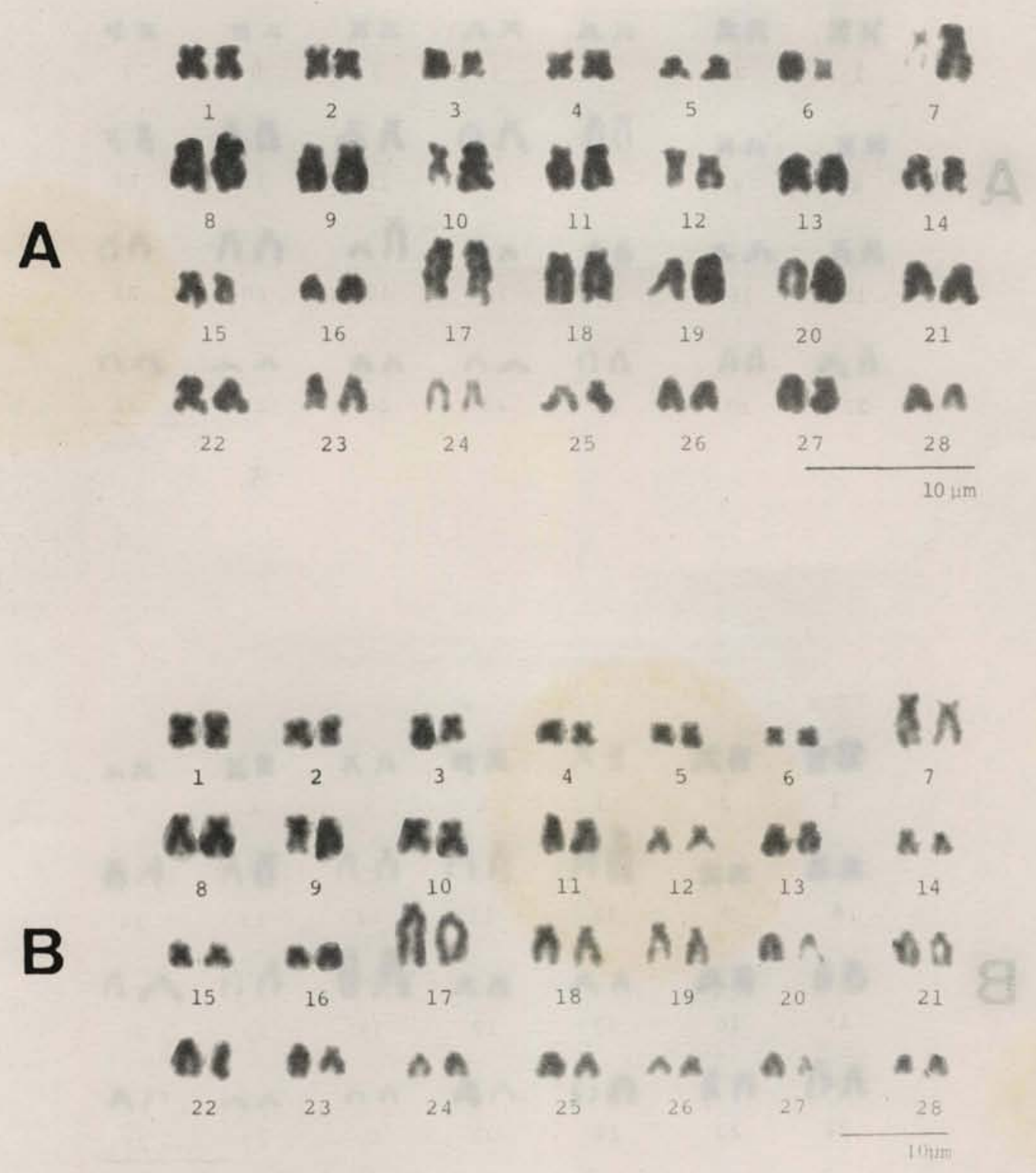

Fig. 2. Selected karyotype of a male (A) and a female (B) Genidens genidens.

$N$. barba, G. genidens and $A$. parkeri have $2 \mathrm{n}=56$. Of these three species, $N$. barba and G. genidens are believed to have similar morphological (Higuchi, 1982), biochemical (Suzuki \& Phan, 1990 a, b) and immunological characteristics (Gomes et al., in preparation). From the osteological (Higuchi, 1982) and biochemical point of view (Suzuki \& Phan, $1990 \mathrm{a}, \mathrm{b})$ A. parkeri is not so similar to $N$. barba and $G$. genidens as are these two later species to each other. Of course, more evidences must be gathered before coming to any definite conclusion but with the development of systematic studies, the karyological characteristics here described could be of some help in the establishment of the relationship between ariid fishes.

Analysing the karyotypes of the three species cited above one could notice some similarities. Besides having the same chromosome number and similar number of msm and stt types they have other features in common. For instance, the first $\mathbf{m}$ pair of their karyotypes is not very big and not very different in size from the subsequent 

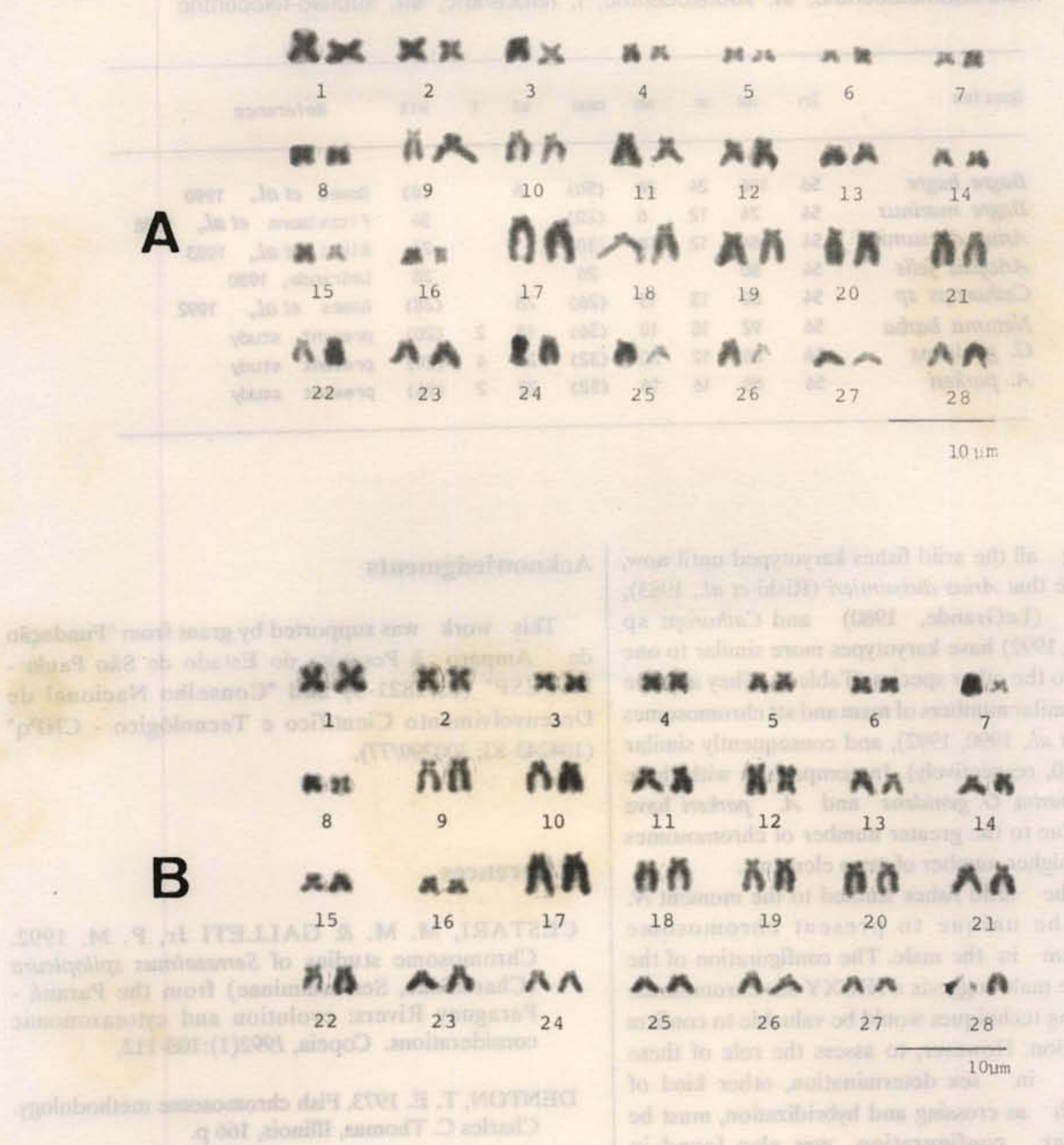

Fig. 3. Selected karyotype of a male (A) and a female (B) Arius parkeri.

ones. The decreasing in size of the $\mathbf{m}$ pairs is slightly more gradual in $N$. barba and $G$. genidens than in $A$. parkeri. The sm chromosomes also show some similarities when comparing the karyotypes of the three species. Their first sm pair is big, the others decrease gradually in size and the last sm one is constituted of small chromosomes. Another feature in common is that their first st pair is the biggest of the complement. Banding techniques would be very useful to verify the possible homologies between chromosome pairs.
In spite of having $2 \mathrm{n}=56, \boldsymbol{B}$. bagre has a very distinct karyotype when compared to $N$. barba, G. genidens and A. parkeri, mainly due to the great differences between their number of msm and stt chromosomes (Table 1).

$B$. bagre and $B$. marinus belong to the same genus and are similar in many aspects in spite of having very distinct karyotypes (Gomes et al., 1990). This variability in chromosome morphology could be, for instance, a characteristic of the genus. More data must be obtained before formulating any hypothesis. 
Table 1. Karyotypes of some ariid catfishes. In parentheses, chromosome types grouped together. AN, arm number; $m$, metacentric; sm, submetacentric; msm, meta-submetacentric; st, subtelocentric; t, telocentric; stt, subtelo-telocentric

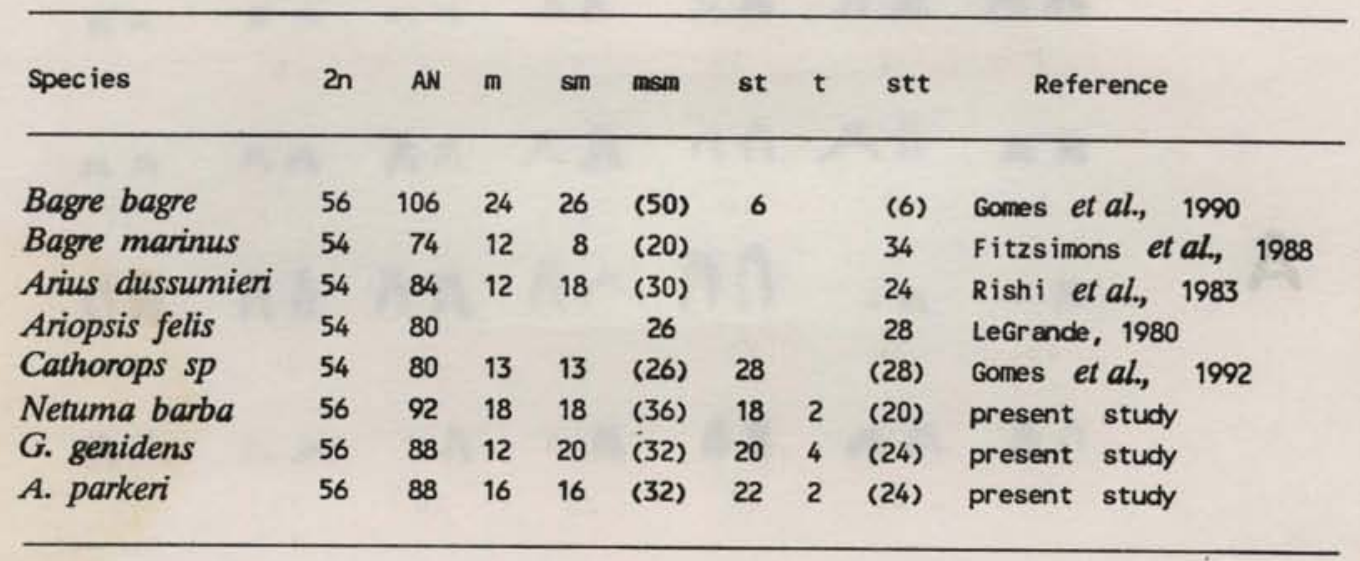

Examining all the ariid fishes karyotyped until now, one can notice that Arius dussumieri (Rishi et al., 1983), Ariopsis felis (LeGrande, 1980) and Cathorops sp (Gomes et al., 1992) have karyotypes more similar to one another than to the other species (Table 1). They all have $2 \mathrm{n}=54$ and similar numbers of $\mathrm{msm}$ and stt chromosomes (see Gomes et al., 1990, 1992), and consequently similar AN $(84,80,80$, respectively). In comparison with these species, N. barba, G. genidens and $A$. parkeri have higher AN due to the greater number of chromosomes and a slightly higher number of msm elements.

Among the ariid fishes studied to the moment $N$. barba was the unique to present chromosome heteromorphism in the male. The configuration of the $19^{\text {th }}$ pair in the male suggests a XX/XY sex chromosome system. Banding techniques would be valuable to confirm this configuration. However, to assess the role of these chromosomes in sex determination, other kind of methods such as crossing and hybridization, must be used. Similar configuration was also found in Siluriformes for Noturus (Rabda) taylory (LeGrande, 1981).

\section{Conclusion}

It's impossible to come to definitive conclusions about the karyological evolution of ariid catfishes with the few data available until now, but it seems that the continuation of this kind of studies, in addition to morphological, osteological and biochemical ones, can contribute to the understanding of the evolution of the family and the relationship between its members.

\section{Acknowledgments}

This work was supported by grant from "Fundaçāo de Amparo à Pesquisa do Estado de Sāo Paulo FAPESP" (81/1821-5) and "Conselho Nacional de Desenvolvimento Científico e Tecnológico - CNPq" $(104243-83 ; 300299 / 77)$.

\section{References}

CESTARI, M. M. \& GALleTI Jr, P. M. 1992. Chromosome studies of Serrasalmus spilopleura (Characidae, Serrasalminae) from the Paraná Paraguay Rivers: evolution and cytotaxonomic considerations. Copeia, 1992(1):108-112.

DENTON, T. E. 1973. Fish chromosome methodology. Charles C. Thomas, Illinois, 166 p.

FIGUEIREDO, J. L. \& MENEZES, N. A. 1978. Manual de peixes marinhos do sudeste do Brasil. II. Teleostei I. Mus. de Zoologia, Univ., São Paulo, 3439.

FITZSIMONS, J. M.; LeGRANDE, W. H. \& KORTH, J. W. 1988. Karyology of the marine catfish Bagre marinus (Ariidae) with an analysis of chromosome number among siluriform fishes. Japan. J. Ichthyol., 35(2):189-193.

GOMES, V.; PHAN, V.N. \& PASSOS, M. J. A. C. R. 1990. The karyotype of a marine catfish, Bagre bagre, from Brazil. Japan. J. Ichthyol., 37(3): 321-323. 
GOMES, V.; PHAN V. N. \& PASSOS, M. J. A. C. R. 1992. The karyotype of Cathorops sp, a marine catfish from Brasil. Bolm Inst. oceanogr., S Paulo, 40(1/2):87-91.

HIGUCHI, H. 1982. Estudo osteológico de bagres marinhos úo litoral sul do Brasil (Osteichthyes; Silurioidei; Ariidae). Dissertação de mestrado. Universidade de Sāo Paulo, Instituto de Biociências. 135 p.

; REIS, E. G. \& ARAÚJO, F. G. 1982. Uma nova espécie de bagre marinho do litoral do Rio Grande do Sul e consideraçōes sobre o gênero Netuma Bleeker, 1858 no Atlântico Sul Ocidental (Siluriformes, Ariidae). Atlântica, Rio Grande, 5:1-5.

HUDSON, R. G. 1976. A comparison of karyotypes and erythrocyte DNA quantities in several species of catfishes (Siluriformes) with phylogenetic implications. PhD Thesis, North Caroline State Univ., Raleigh. In.: LeGrande, W. et al. 1984. Copeia, (4):873-878.

KIRPICHNIKOV, V. S. 1981. Genetic bases of fish selection. Springer-Verlag, Berlin, 411 p.

KRAMER, B. 1990. Electrocommunication in teleost fishes. Behaviour and Experiments. Zoophysiology, v. 29. Springer-Verlag, Germany, 240 p.

LAUDER, G. V. \& LIEM, K. F. 1983. Patterns of diversity and evolution in ray-finned fishes. In: Northcutt, R. G. \& Davis, R. E. eds Fish neurobiology. Univ Michigan Press, Ann Arbor, 1-24.

LeGRANDE, W. H. 1980. The chromosome complement of Arius felis (Silurifomes, Arïdae). Japan. J. Ichthyol., 27(1):82-84.

1981. Chromosomal evolution in North American catfishes (Siluriformes: Ictaluridae) with particular emphasis in the madtoms, Noturus. Copeia, (1):33-52.
LeGRANDE, W. H. \& FITZSIMONS, J. M. 1976. Karyology of the mullets Mugil curema and $M$. cephalus (Perciformes; Mugilidae) from Louisiana. Copeia, (2):388-391.

; DUNHAM, R. A. \& SMITHER $\overline{M A N}, \mathbf{R}$. O. 1984. Karyology of three species of catfishes (Ictaluridae: Ictalurus) and four hybrid combinations. Copeia, (4):873-878.

LEVAN, A.; FREDGA, K. \& SANDBERG, A. A. 1964. Nomenclature for centromeric position on chromosomes. Hereditas, 52:201-220.

RISHI, K. K; SINGH, J. \& HAOBAM, M. S. 1983. Karyological study on a marine catfish, Arius dussumieri (Val.) (Ariidae: Siluriformes). Chrom. Inf. Serv., (34):7-9.

SUZUKI, H. \& PHAN, V. N. 1990a. Electrophoretic study on intraspecific variations and interspecific relationships of marine catfishes (Siluriformes, Ariidae) of Cananéia (São Paulo, Brazil). 1. General proteins of eye-lens and skeletic muscle. Bolm Inst. oceanogr., S Paulo, 38(1):31-42.

\& 1990b. Electrophoretic study on intraspecific variations and interspecific relationships of marine catfishes (Siluriformes, Ariidae) of Cananéia (São Paulo, Brazil). 2. Isozymes of skeletic muscle. Bolm Inst. oceanogr., S Paulo, 38(1):43-55.

TAYLOR, W. R. \& MENEZES, N. A. 1977. In: FISHER, W., ed. 1978. FAO species identification sheets for fishery purposes. Western Central Atlantic Fishing Area 31. Rome, FAO. V. 1.

UYENO, T.; MILLER, R. R. \& FITZSIMONS, J. M. 1983. Karyology of the cyprinodontoid fishes of the Mexican family Goodeidae. Copeia, (2):497-510.

(Manuscript received 12 May 1993, revised 24 May 1994, accepted 1 June 1994) 